\title{
A new spot-thoraxed species of Drosophila from the Atlantic Forest of southeastern Brazil (Diptera, Drosophilidae)
}

\author{
Carlos R. Vilela ${ }^{1} \&$ Francisca C. do Val $^{2}$
}

\begin{abstract}
${ }^{1}$ Departamento de Biologia, Instituto de Biociências, Universidade de São Paulo. Caixa Postal 11461, 05422-970 São Paulo-SP, Brazil. E-mail: crvilela@ib.usp.br

${ }^{2}$ Museu de Zoologia, Universidade de São Paulo. Avenida Nazaré 481, 04263-000 São Paulo-SP, Brazil.

E-mail: fracdval@usp.br
\end{abstract}

\begin{abstract}
Resumo. Uma nova espécie de Drosophila da Mata Atlântica do sudeste do Brasil com pintas no tórax (Diptera, Drosophilidae). Drosophila boraceia sp. nov. é descrita, e sua terminália masculina ilustrada, a partir de um macho coletado na Estação Biológica de Boracéia, Salesópolis, Estado de São Paulo, Brasil. À primeira vista, ela pode ser facilmente confundida com as espécies de Drosophila do subgrupo fasciola do grupo repleta, por apresentar um padrão de fusão das pintas do tórax semelhante àquele típico das espécies daquele subgrupo, das quais difere principalmente por possuir uma terminália masculina estruturalmente diferente. Entretanto, alguns componentes da terminália masculina de Drosophila boraceia sp. nov. apresentam uma certa semelhança com aqueles encontrados em Drosophila atalaia Vilela \& Sene, 1982, espécie não agrupada e que também apresenta pintas no tórax.
\end{abstract}

Palavras-Chave. Drosophilinae; Estado de São Paulo; Floresta Pluvial; região Neotropical; terminália masculina.

\begin{abstract}
Drosophila boraceia sp. nov. is described from a single male specimen collected at the Estação Biológica de Boracéia, Salesópolis, state of São Paulo, Brazil. At first inspection it looks like a species of Drosophila belonging to the fasciola subgroup of the repleta group, mainly because of the fasciola-like pattern of fused spots on the thorax. However, mostly due to the quite distinct structures of the male terminalia, it seems to be more similar to one ungrouped and also spot-thoraxed South American species, Drosophila atalaia Vilela \& Sene, 1982. Illustrations of the terminalia are also provided.
\end{abstract}

Keywords. Drosophilinae; male terminalia; neotropics; rain forest; state of São Paulo.

All species of Drosophila belonging to the annulimana group and most of those assigned to the repleta group, both endemic to the New World, have each seta and setula on the thorax arising from a dark spot. This clear-cut feature has traditionally allowed a quick identification of the flies included in those two groups. The large spotted and humpbacked flies with shine, amber-colored, slightly wrinkled wings are members of the annulimana group, while the remaining smaller spotted flies mostly belong to the repleta group. However, in many drosophilid collections it is possible to find several small spotted specimens apparently belonging to the latter group, but labelled as undetermined species. During the past decades we have had the opportunity to study some specimens of those undetermined species which are deposited in several collections.

In the early eighties (Vilela \& Sene 1982) one of those undetermined species was described as Drosophila atalaia Vilela \& Sene, 1982, which was not assigned to any group. Later on, Vilela \& Pereira $(1985,1993)$ and Vilela \& Bächli (1990) were able to recognize a cluster of three spotted species (Drosophila peruensis Wheeler, 1959, D. tucumana Vilela \& Pereira, 1985 and D. urubamba Vilela \& Pereira, 1993) clearly belonging to the the Drosophila guarani species group, previously not thought to include spotted species, although a kind of tiny and not well defined spots can be seen on the thorax of Drosophila guaraja King, 1947.
It is possible that some authors have mistakenly identified as members of the Drosophila repleta group several species of Drosophilidae with spotted thorax, which currently belong to different groups of Drosophila and even distinct genera, because they were unware of the evolutionary recurrence of the spotted thorax feature in species from different lineages. This was the case of the following species (current position in parentheses): Scaptodrosophila obsoleta (Malloch, 1923) (inornata group), Balara poecilithorax (Malloch 1925)(ungrouped), Drosophila annulimana Duda, 1927 (annulimana group), Drosophila pachea Patterson \& Wheeler, 1942 (nannoptera group), Drosophila chinoi Okada, 1956 (junior synonym of D. repletoides Hsu, 1943; tumiditarsus group), Drosophila serenensis Brncic, 1957 (ungrouped), Drosophila aureata Wheeler, 1957 (ungrouped), Drosophila peruensis Wheeler, 1959 (guarani group) (PATTERSON \& Stone 1952; VILELA 1983; WHEELER 1986).

Although quite different from the above-mentioned species and/or groups, other examples of spotted thorax species of Drosophilidae are: Cacoxenus guttatus (Hardy \& Wheeler, 1960), Gitona americana Patterson, 1943 and Gitona sonoita, Wheeler, 1949 (Nearctic), Rhinoleucophenga punctulata Duda,1929 (Neotropical), Cacoxenus argyreator Frey, 1932 and Cacoxenus inquilinus Hendel, 1933 (Palaearctic) (Malogolowkin 1946; McAlpine 1968).

The purpose of the present paper is to present the 
description of a new spotted species of Drosophila which apparently does not belong to any of the described groups of American Drosophila. The description is based on a single pinned male specimen collected at an Atlantic Forest reserve of ca. 96 ha named Estação Biológica de Boracéia (TRAVAssos Filho \& CAMARgo 1958), deposited in the collection of the Museu de Zoologia da Universidade de São Paulo and previously considered an undescribed species mistakenly assigned to the Drosophila repleta group by VAL \& KANESHIRO (1988: 196).

\section{MATERIAL AND METHODS}

Just one pinned (double-mounted) male specimen was analyzed in the present study. The label data attached to the pin are cited under "type material". Refer to VILELA \& BächLI (2000) for morphological terminology and measurements, as well as for dissection, preparation of slide mounts, and illustrations of terminalia.

\section{Drosophila boraceia sp. nov.} (Figs. 1-8)

Undescribed repleta group species; Val \& Kaneshiro, 1988: 196.

Type material. Holotype male (postabdomen dissected), labelled [clarifying notes in brackets] "Est.[Estação] Biol.[Biológica] Boracéia Salesópolis, SP [São Paulo]- Br.[Brasil] 7-8-VIII-79 F. Gomes col. I Drosophila boraceia $0^{x}$ Vilela \& Val / HOLOTIPO [red label]". The disarticulated terminalia are kept in a microvial filled with glycerin and attached by the stopper to the pinned specimen. Type locality: Estação Biológica de Boracéia ( $23^{\circ} 40^{\prime} \mathrm{S}, 45^{\circ} 50^{\prime} \mathrm{W}$ ), municipality of Salesópolis, state of São Paulo, Brazil

Diagnosis. Body color light brown; frons pollinose, yellowish brown in anterior area; frontal index 1.0; facial carina narrow, sulcate; scutum grayish brown, pollinose with confluent spots at base of setae, forming 4 slightly darker brown stripes, 2 inside dc lines and 2 interrupted ones outside dc line s; costal section I apically black; $\mathrm{C}$ index $=3.4$; ac index $=1.9 ; 4 \mathrm{c}$ index $=0.8$; abdomen yellowish brown with broad marginal brown bands medially interrupted, paramedially slightly broadened, laterally extended to anterior margin.

Description. Head mainly yellowish brown. Frontal length $=0.44 \mathrm{~mm}$; top to bottom width ratio 1.5 . Frontal triangle indistinct; ocellar triangle grayish brown, about $50 \%$ of frontal length. Frontal vittae reddish brown. Frontorbital plates with subtle dark brown spots at base of orbitals, diverging from eye margin, about $3 / 4$ frontal length. Mid orbital behind anterior one, distance of posterior orbital to anterior about the same as that to inner vertical. Length ratio of anterior to posterior orbital 0.8 , of mid to anterior orbital 0.7 ; poc $43 \%$, oc $57 \%$ of frontal length; vt index $=1.1$; vibrissal index $=0.6$. Cheek index about 7.4. Eye index $=1.4$. First flagellomere short-haired; length to width ratio $=1.4$. Arista with 4 upper and 2 lower branches plus terminal forked, inner branches relatively long. Proboscis brown, palpi light brown.
Thorax brown; length $=1.4 \mathrm{~mm}$; $\mathrm{h}$ index $=0.8 ; 8$ rows of acrostichals. Transverse distance of dorsocentrals about $2.3 \mathrm{x}$ longitudinal distance; dc index 0.6. Scutellum medially brownish, laterally pale with distinct dark spots around scut; scut position index 0.6; basal scut convergent; scut index = 0.9 ; two asymmetrical prescutellars; sterno index $=0.8$; mid katepisternal about $27 \%$ of the anterior one. Halteres basally brown, distally lighter. Legs brown, tibiae distally slightly darker, tarsi yellow.

Wing brown, costal section I apically black, crossveins slightly darker than longitudinal veins; length $2.6 \mathrm{~mm}$; length to width ratio 2.0. Indices: $\mathrm{C}=3.4, \mathrm{ac}=1.9, \mathrm{hb}=0.4,4 \mathrm{C}=0.8,4 \mathrm{v}$ $=1.6,5 \mathrm{x}=1.1, \mathrm{M}=0.5$, prox. $\mathrm{x}=0.4$.

Male terminalia (Figs. 1-8). Epandrium mostly microtrichose with about 11 lower and no upper setae; ventral lobe not covering surstylus. Cerci mostly microtrichose, anteriorly fused to epandrium at lower half. Surstylus mostly microtrichose, with 11 cone-shaped prensisetae, about 9 long outer setae and ca. 5 long inner setae; anterior margin at the same level as anterior margin of ventral lobe of epandrium. Decasternum as in Fig. 2. Hypandrium shorter than epandrium, somewhat square-shaped; dorsal arch absent; gonopod mostly fused to hypandrium, bearing one small setae on the anterior inner margin; posterior margin strongly concave. Aedeagus medially hunchbacked in profile, subtly invaginated at tip, bearing a pair of short, sharply pointed, subapical spurs, which reach the paraphyses; dorsal cleft reduced solely to the anterior opening, adjacent to the fusion aedeagus-aedagal apodeme. Aedeagal apodeme shorter than aedeagus, slightly flattened laterally. Ventral rod absent. Paraphysis anteriorly pointed, distally rounded with 1 small setae, linked to gonopod by membranous tissue.

Relationships. It belongs to the subgenus Drosophila but can not be assigned to any of the recognized groups of the genus Drosophila. However, it is somewhat similar to the ungrouped Neotropical species Drosophila atalaia Vilela \& Sene, 1982, from which it differs mainly by having the anterior corner of ventral lobe of epandrium not prolonged downwards, a hypandrium clearly devoid of dorsal arch, and a much more stout aedeagus, which is clearly hunchbacked in lateral view and devoid of minute, lateral, subdistal scales. It can be confused at a first glance with the species of the fasciola subgroup of the repleta group, from which it differs mostly because in Drosophila boraceia sp. nov. the epandrium is devoid of upper setae, the surstylus is mostly microtrichose, the hypandrium is mostly fused to the gonopods and squareshaped instead of triangle-shaped, the dorsal cleft of aedeagus is reduced to a narrow anterior opening.

Etymology. The epithet is a noun in apposition and an allusion to the site of collection of the holotype.

Acknowledgments. We are grateful to Mr. Firmino Gomes for collecting the specimen upon which the description of the new species was based. 

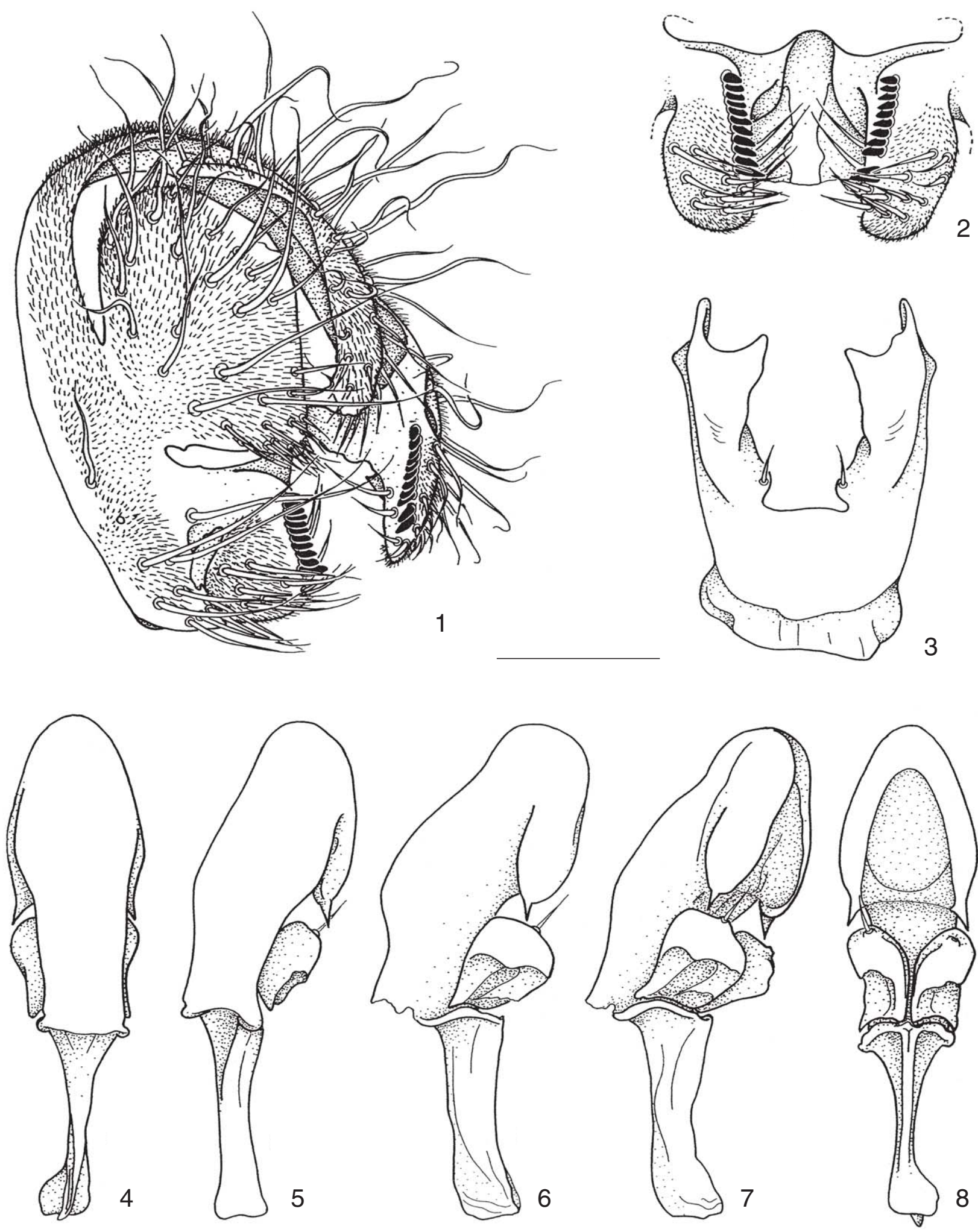

Figs. 1-8. Male terminalia of Drosophila (Drosophila) boraceia sp. nov., holotype. 1, epandrium, cerci, surstyli and decasternum, oblique posterior view; 2, surstyli and decasternum, posterior view; 3, hypandrium and gonopods, posterior view; 4-8, aedeagus, aedeagal apodeme, and paraphyses, several views from dorsal through ventral. All figures were drawn to the same scale. Scale bar $=0.1 \mathrm{~mm}$. 


\section{REFERENCES}

Malogolowkin, C. 1946. Sôbre o gênero "Rhinoleucophenga"com descrição de cinco espécies novas (Drosophilidae, Diptera). Revista Brasileira de Biologia 6(3): 415-426.

McAlpine, J. F. 1968. An annotated key to drosophilid genera with bare or micropubescent aristae and a revision of Paracacoxenus (Diptera: Drosophilidae). Canadian Entomologist 100: 514-532.

Patterson, J. T. \& W. S. Stone. 1952. Evolution in the genus Drosophila. New York, MacMillan, 610 p.

Travassos Filho, L. \& H. F. DE A. Camargo. 1958. A Estação Biológica de Boracéia. Arquivos de Zoologia 11(1): 1-21.

VAL, F. C. \& K. Y. Kaneshiro. 1988. Drosophilidae (Diptera) from the Estação Biológica de Boracéia, on the coastal range of the state of São Paulo, Brazil: geographical distribution, p. 189-203. In: P. E.Vanzolini \& W. R. Heyer (eds.). Proceedings of a workshop on Neotropical distribution patterns. Rio de Janeiro, Academia Brasileira de Ciências, 488 p.

Vilela, C. R. 1983. A revision of the Drosophila repleta species group (Diptera, Drosophilidae). Revista Brasileira de Entomologia 27(1): 1-114.

Vilela, C. R. \& G. BÄChli. 1990. Taxonomic studies on neotropical species of seven genera of Drosophilidae (Diptera). Mitteilungen der schweizerischen Entomologischen Gesellschaft 63 (suppl.): 1-332.

VilelA, C. R. \& G. BÄChli. 2000. Morphological and ecological notes on the two species of Drosophila belonging to the subgenus Siphlodora Patterson \& Mainland, 1944 (Diptera, Drosophilidae). Mitteilungen der schweizerischen Entomologischen Gesellschaft 73(1-2): 23-47.

Vilela, C. R. \& M. A. Q. R. Pereira. 1985. Notes on two species of spotthoraxed Drosophila belonging to the guarani group (Diptera, Drosophilidae). Revista Brasileira de Entomologia 29(3/4): 435- 442 .

Vilela, C. R. \& M. A. Q. R. Pereira. 1993. A case of misidentification of a Neotropical species of Drosophila (Diptera, Drosophilidae) belonging to the guarani group. Revista Brasileira de Entomologia 37(4): 819- 820.

Vilela, C. R. \& F. M. SEnE. 1982. A new spotted thorax species of the genus Drosophila (Diptera, Drosophilidae). Revista Brasileira de Entomologia 26(3/4): 343-347.

Wheeler, M. R. 1986. Catalog of the World's Drosophilidae, p. $395-$ 409. In: M. Ashburner, H. L. Carson \& J. R. Thompson, JR. (eds) The Genetics and Biology of Drosophila, v. 3e. London, Academic, xviii+548 p.

Received 29.VII.2003; accepted 30.XI.2003 